\title{
Effects of Different Estrous Synchronization Methods on the Composition of Simmental Cow's Milk
}

\author{
Ibrahim Seker' ${ }^{1}$ Ali Risvanli², Mehmet Calicioglu ${ }^{3}$, Gokhan Kursad Incili ${ }^{3}$ \& Nevzat Saat ${ }^{4}$
}

\begin{abstract}
Background: Estrous synchronization is one of the primary applications performed to improve the fertility and to consolidate the parturition times in dairy cattle farms. Since the primary objective is to increase fertility regardless of the method of synchronization used, the effect of this process on the udder health and the quality of milk is generally ignored. Therefore, in the present study, the aim was to investigate the effect of different estrous synchronization methods t on the milk quality in a dairy cattle farm.

Materials, Methods \& Results: In this study, a total of 100 Simmental cows the same farm under good management practices were used. The animals were randomly divided into 4 groups of 25 cows each. The animals in the $1^{\text {st }}$ group were used as a control group without any treatment. Progesterone-releasing intravaginal device (PRID) was inserted to the animals in the $2^{\text {nd }}$ group, double dose of prostaglandin $\mathrm{F}_{2}$ alpha $\left(\mathrm{PGF}_{2}\right.$-alpha) with 11 days apart was applied to the animals in the $3^{\text {rd }}$ group, and the Ovsynch protocol was applied to the animals in the $4^{\text {th }}$ group. Starting from the first day of the applications, milk samples from each milk tank belonging to the groups were taken, kept frozen for 3 months and analyzed for the levels of fat, nonfat solids, density, protein, lactose and minerals over the course of one month. According to the results, the minimum milk fat content was found in the PRID group as $2.47 \pm 0.354 \%$, and the highest value was in the $\mathrm{PGF}_{2}$-alpha group as $3.58 \pm 0.207 \%$. The difference in milk fat ratio between the groups was found to be significant $(P<$ $.05)$. However, the differences between the groups for other parameters were not significant $(P>.05)$.

Discussion: Among the reasons for the low values of the milk fat rates obtained in the present study than the mean values of all lactation milk fat rates of the Simmental breed, the effect of the lactation period in which the milk samples were collected comes to mind. Because, as we know, the first 45-60 day period following the start of lactation after parturition in cattle is accepted as the period in which daily milk yield reaches to the maximum level of the lactation period. This period lasts for a certain period of time, and then starts to decrease gradually. Among the non-hereditary factors, the most important factor causing changes in the composition of the milk and its amount is the lactation period. In this study, the significant difference in the milk fat rates between the control and the application groups is quite remarkable compared to the low level of milk fat rates in the milk in all groups. According to the multiple comparison test results to determine which groups these differences arise from, the difference was found to be particularly between the PGF $_{2}$-alpha group and PRID group. In this study, no significant effects of different synchronization methods on all components of the milk except the milk fat and the density values were determined. But results indicate that Ovsynch group was the synchronization group that caused the minimum change in milk fat compared to the other groups.
\end{abstract}

Keywords: estrous synchronization, composition of milk, Simmental. 


\section{INTRODUCTION}

High milk yield and fertility ratio are always targeted in dairy cattle farming. However, genetically, it is not quiete possible for the animals to maintain these two parameters at high levels. The most ideal state is one of the two to be at high levels, and the other to be in optimal conditions. The maintenance of high milk production is possible by managing the fertility at an optimum level. However, the increase in the milk yield brings many fertility problems. To prevent the fertility loss as a result of an increase in the milk yield per animal and the increase in the number of animals in recent years, synchronization protocols have begun to be used extensively. When selecting these protocols, the status of the farm should be considered, and the protocol must be selected according to the problems encountered in the farm. However, while selecting these protocols, increasing the fertility yield is aimed rather than the quality of milk and the udder health [2,27].

In some studies, increase in the protein content of milk related to the synchronization applications and during the estrous has been reported [18]. However, it was also recorded that the fat and lactose contents of the milk were not affected by the applications [9].

In this regard, this research was conducted to determine the possible effects of different synchronization methods used in Simmental cattle on the composition of milk.

\section{MATERIALS AND METHODS}

The data used in the present study was obtained from a dairy cows farm in Elazig (Turkey). There were 200 Simmental cows with ages ranging between 2-7 years in the farm. The study was performed between June 2014-June 2015. The mean somatic cell count of the milk taken from the bulk tank (SCC) of the herd was determined in a previous study as $<150.000$ cell/ $\mathrm{mL}$. The SCC in the farm was found to increase during the estrous synchronization applications [22].

\section{Animals and the study protocol}

A total of 100 cows with ages ranging between 2-4 years were chosen from the cattle in the farm and were randomly divided into 4 groups, provided to be at similar ages and yield characteristics.

The cows in the $1^{\text {st }}$ group served as a control group. These cows were 40-60-days-old postpartum and did not receive ant any application $(\mathrm{n}=25)$.
The cattle in the $2^{\text {nd }}$ group received intravaginal device with progesterone release (PRID Delta) $)^{1}(\mathrm{n}=$ 25 ). This device was placed and remained in the vagina of the cows that were 40-60-day old after parturition for 7 days. After removal, the cows were inseminated (PRID).

The cows in the $3^{\text {rd }}$ group received double dose IM $25 \mathrm{mg}$ dinoprost $\left(\text { Enzaprost }^{\circledR}-\mathrm{T}\right)^{1}$ with 11 days interval $(n=25)$ then the cows were inseminated ( $\mathrm{PGF}_{2}$-alpha).

Tha Ovsynch protocol was applied to the cows in the $4^{\text {th }}$ group $(n=25)$. For this purpose, 100 $\mu \mathrm{g}$ gonadorelin diacetate tetrahydrate (Ovarelin) ${ }^{1}$ on the $0^{\text {th }}$ day, $25 \mathrm{mg}$ dinoprost $\left(\text { Enzaprost }^{\circledR}-\mathrm{T}\right)^{1}$ on the $7^{\text {th }}$ day, and $100 \mu$ g gonadorelin diacetate tetrahydrate (Ovarelin) ${ }^{1}$ on the $9^{\text {th }}$ day was applied IM to the cows, and fixed-time insemination was performed between the $16^{\text {th }}-24^{\text {th }} \mathrm{h}$ (Ovsynch).

\section{Sample collection and composition analyses of milk}

To determine the effects of different synchronization applications on the composition of the milk in Simmental cows, the milk samples were collected daily from the portable Bulk Tank Milk (BTM) of each group into $10 \mathrm{~mL}$ of tubes. The samples were frozen and stored at $-20^{\circ} \mathrm{C}$ for 3 months until analyzed. The milk samples were thawed by keeping at $4{ }^{\circ} \mathrm{C}$ for $12 \mathrm{~h}$ prior to the analysis, and then the temperature was brought to room temperature $\left(20^{\circ} \mathrm{C}\right)$. The milk samples were vortexed just before the analyses to be homogenized. The quantities of fat, nonfat solids, density, protein, lactose and minerals were determined in all samples. These analyses were performed using the Laktoscan ${ }^{2}$ device. The measurements were repeated in order to obtain more reliable results, and the average values of these repetitions were used for the statistical analysis.

\section{Statistical analysis}

The descriptive statistics of the data were calculated primarily. The one-way ANOVA analysis of variance was performed in order to detect the effects of different synchronization methods on the ratios of milk fat, nonfat solids, density, protein, lactose and minerals. In comparison of the control group and the other groups to which different synchronization methods were applied, the Duncan multiple comparison test was used for the parameters in which significance was detected at the variance analyses. These analyses were performed using SPSS software [1]. 
RESULTS

The rates of milk fat, nonfat solids, protein, lactose and minerals, the descriptive values of densities and the results of the statistical analyses of the groups in the study have been presented in Table 1. Before the details, it is important to note that the values were representing the average of 25 cows in each group because the samples were taken from the BTM of each group. There was no data from individual cows and therefore, comparing the means of groups of cows was not possible.

Descriptive statistics of the data indicate that the lowest value for the milk fat rate was determined

Table 1. Mean values of the milk composition of cows treated with different synchronization methods.

\begin{tabular}{|c|c|c|}
\hline Milk composition (\%) & $\begin{array}{c}\text { Groups } \\
(\mathrm{n}=30)\end{array}$ & Mean \pm Standard deviation \\
\hline \multirow{4}{*}{ Fat } & Control & $2.90 \pm 0.229^{\mathrm{ab}}$ \\
\hline & Ovsynch & $2.93 \pm 0.218^{\mathrm{ab}}$ \\
\hline & $\mathrm{PGF}_{2}$-alpha & $3.58 \pm 0.207^{\mathbf{b}}$ \\
\hline & PRID & $2.47 \pm 0.354^{\mathrm{a}}$ \\
\hline \multirow{6}{*}{ Nonfat Solids } & $P$ & $*$ \\
\hline & Control & $9.20 \pm 0.111$ \\
\hline & Ovsynch & $9.08 \pm 0.135$ \\
\hline & $\mathrm{PGF}_{2}$-alpha & $9.25 \pm 0.113$ \\
\hline & PRID & $9.31 \pm 0.089$ \\
\hline & $P$ & - \\
\hline \multirow{4}{*}{ Density } & Control & $1.03 \pm 0.000$ \\
\hline & Ovsynch & $1.03 \pm 0.000$ \\
\hline & $\mathrm{PGF}_{2}$-alpha & $1.03 \pm 0.000$ \\
\hline & PRID & $1.03 \pm 0.000$ \\
\hline \multirow{6}{*}{ Protein } & $P$ & - \\
\hline & Control & $3.32 \pm 0.038$ \\
\hline & Ovsynch & $3.29 \pm 0.048$ \\
\hline & $\mathrm{PGF}_{2}$-alpha & $3.35 \pm 0.041$ \\
\hline & PRID & $3.35 \pm 0.037$ \\
\hline & $P$ & - \\
\hline \multirow{4}{*}{ Lactose } & Control & $4.88 \pm 0.064$ \\
\hline & Ovsynch & $4.84 \pm 0.074$ \\
\hline & $\mathrm{PGF}_{2}$-alpha & $4.92 \pm 0.072$ \\
\hline & PRID & $4.92 \pm 0.053$ \\
\hline \multirow{6}{*}{$\mathrm{NaCl}$} & $P$ & - \\
\hline & Control & $0.73 \pm 0.009$ \\
\hline & Ovsynch & $0.72 \pm 0.011$ \\
\hline & $\mathrm{PGF}_{2}$-alpha & $0.73 \pm 0.009$ \\
\hline & PRID & $0.72 \pm 0.008$ \\
\hline & $P$ & - \\
\hline
\end{tabular}

$-: P>.05, *: P<.05$, a,b,c: The differences between the mean values that carry different superscripts in the same column are significant $(P<.05)$. 
as $2.47 \pm 0.354 \%$ in the PRID group, and the highest value as $3.58 \pm 0.207$ in the $\mathrm{PGF}_{2}$-alpha group.

The variation in milk fat rates of the groups for 30 days has been presented in Figure 1.

As seen in Figure 1, in all groups, the line graphs obtained from the values of milk fat rates did not show a regular trend during the 30 days. However, the differences in milk fat rate, particularly between the $\mathrm{PGF}_{2}$-alpha and PRID groups, are evident. Generally, the variation figures in intermittent increasing and decreasing trends of the values of milk fat rates in all groups showed similarities. At the beginning of the research, just after the day the application of preparations were made for synchronization, a significant decrease in milk fat rate was determined in all groups, except for the Ovsynch group. This decrease in the Ovsynch group was at very low levels. However, in the period from the first day of the research to the end of the $30^{\text {th }}$ day, the group with the greatest similarity with the control group in terms milk fat rates was the Ovsynch group.

\section{DISCUSSION}

The mean milk fat rates for all groups were determined to be between $2.47 \%$ and $3.58 \%$ in the study (Table 1). These values were determined to be lower than the reported values of 3.72-3.77\% for the Simmental cows in Russia for the same lactation period [26] and lower than the reported values for those in Turkey (3.9-4.0\%) [24,25]. The milk fat rates obtained from the present study were found to be similar to the mean fat rates $(3.50 \%)$ of the Simmental cattle in lactation in Albania [6]. On the other hand, the reported mean fat rates for lactation for Simmental breed in some countries were between $3.68 \%$ [26] and $4.14 \%$ $[14,20]$, and these values were found to be higher than the milk fat rates found in the presented study.

Among the reasons for the low values of the milk fat rates obtained in the present study than the mean values of all lactation milk fat rates of the Simmental breed, the effect of the lactation period in which the milk samples were collected comes to mind. Because, as we know, the first 45-60 day period following the

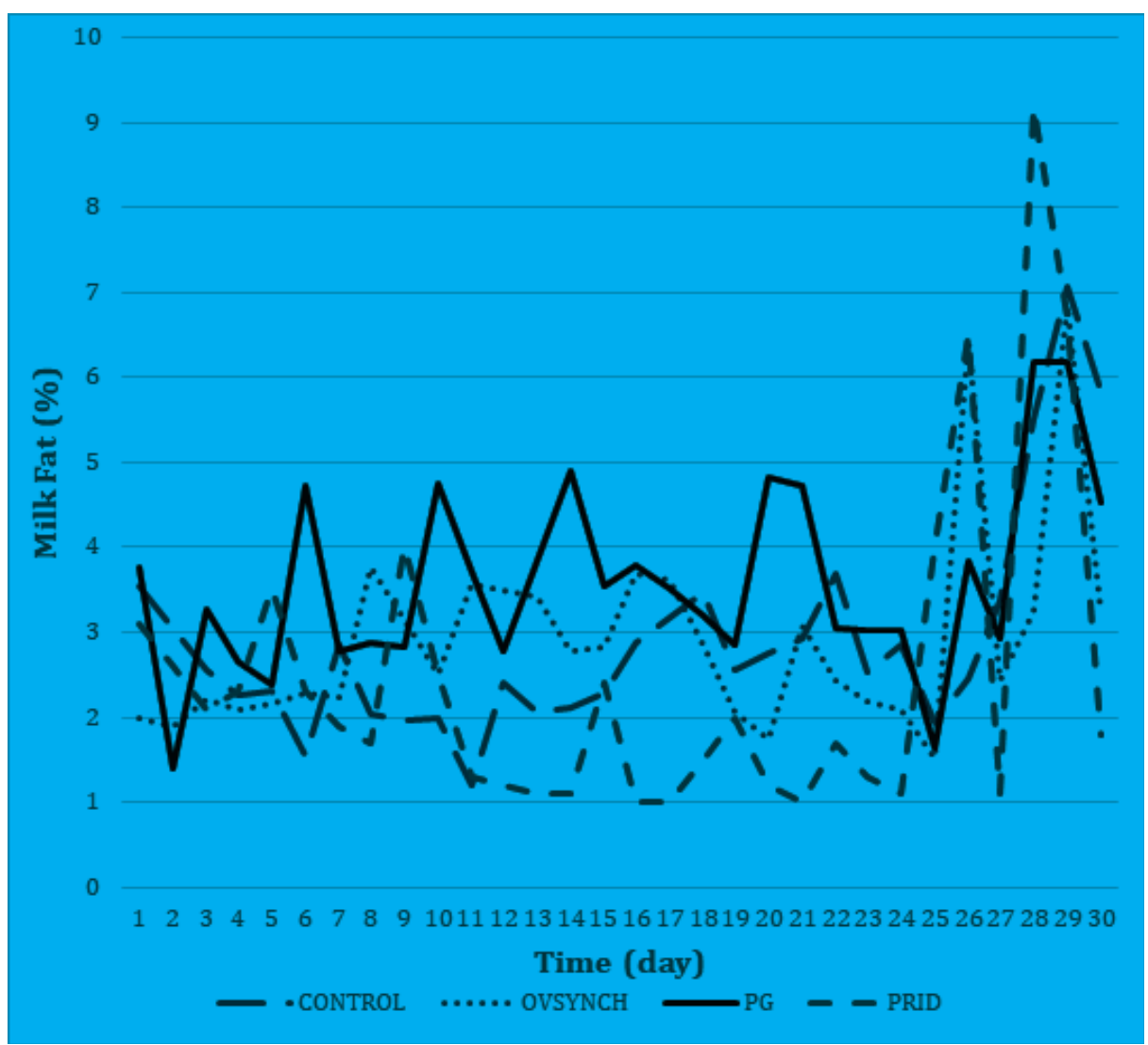

Figure 1. The variation of the milk fat rates in the study groups. 
start of lactation after parturition in cattle is accepted as the period in which daily milk yield reaches to the maximum level of the lactation period. This period lasts for a certain period of time, and then starts to decrease gradually. Among the non-hereditary factors, the most important factor causing changes in the composition of the milk and its amount is the lactation period $[3,11]$. During the lactation period, the components of the milk including milk fat and nonfat solids do not change in the same manner and rate. In other words, some components increase while some decrease [3,5]. It has been known that milk fat ratio decrease in the period in which the milk yield increases. These two parameters are inversely correlated [5]. Considering that the milk samples were collected in the $3^{\text {rd }}$ month of lactation, effects of this inverse relation between milk yield and fat ratio may be more evident. Despite the increase in the amount of milk in the first 2 months of lactation, it was reported that the amount of fat decreases, descend to the lowest level in a few months, and slowly begins to rise in the subsequent months, increasing thoroughly at the $6^{\text {th }}$ month [10]. Furthermore, in the present study, the days of milk collection being the days in which the milk yield is still at the highest levels and the similar condition being also determined in the control group, supports the presence of a compatible change with the above-mentioned literature.

Another reason for the low levels of milk fat rates in all the groups included in the study, especially in the control group, is considered to be the temperature conditions, period and the exposure to thawing and homogenization until the analysis of the collected milk samples during the research for composition. Yet, in some studies, it was reported that the milk samples to be stored at different temperature conditions by freezing, the period of conservation, their thawing, and homogenization applications before the analysis for their composition, might cause a change. A decrease, particularly in the milk fat rates, and the fat and total nonfat solids rates were reported to be higher in the fresh milk than the frozen and long-time-stored milk [29-31]. This situation has been reported to occur generally as a result of disruption of the milk fat globules by lipolysis, the enzymatic degradation of triacylgylcerol, the microbial activity or lipid peroxidation and the disrupted fat globules to adhere to the surface of the tube or plastic containers easily, during the freezing procedure at low tempe- ratures and long-term keeping [13,18,31]. Similarly, there are other studies performed with sheep and human milk, reporting the decrease in the fat content of frozen-thawed milk [7,28,31]. Some other studies in fact, have reported that the freezing and storage time of the milk had no effect on the total dry matter, protein and lactose content of the milk [12,29,31].

In this study, the significant difference in the milk fat rates between the control and the application groups is quite remarkable compared to the low level of milk fat rates in the milk in all groups. According to the multiple comparison test results to determine which groups these differences arise from, the difference was found to be particularly between the $\mathrm{PGF}_{2}$-alpha group and PRID group (Table 1). Some researchers have also stated that the preparations used during different synchronization methods may have an impact on the composition of milk [15-18]. Some of these applications have been reported to reduce the fat rate in the milk $[16,17]$. In this respect, agreements between the literature reports and the results of the current study have been determined. In addition, there are researchers reporting that application of different synchronization methods in goats has no significant effect on the milk fat rate [9]. The differences between the results obtained from this study, particularly the milk fat rate results and the results obtained from the other studies are thought to be caused by the animal species, the differences in the methods, the differences of the preparations used, their doses, the application period, the application timing, and the other factors related to the cattle (lactation period, lactation age, greed, etc.). In addition to determining whether different synchronization methods have effects on some milk components, determining the extent and the duration of this occurring effect is also important. Nevertheless, whether the effects of different synchronization methods on the milk quality has an economic significance or not especially in terms of dairy technology and dairy industry should be demonstrated

In a study investigating the effects of different methods used in cattle for synchronization on the SCCs in milk, the greatest similarity to the control group in terms of SCC values was seen in the Ovsynch group, and it was recommended for milk SCC of the synchronization methods used in the research [23]. 
In this study, no significant effects of different synchronization methods on all components of the milk except the milk fat and the density values were determined. The mean protein rates in the milk for all groups were between $3.29-3.35 \%$. It was found to be similar to the level of 3.33-3.39\%, which was reported for the Simmental cattle in Russia for the same lactation period [26]. It was found to be lower than the milk protein rates for lactation reported for the Simmental cattle in Turkey (3.74$3.9 \%$ ) $[24,25]$. The overall reported protein rates for general lactation in Simmental breed grown in other countries were recorded as 3.30-3.61\% [4,19,21].

In the presented study, the mean milk lactose rates in all groups were found to be between 4.84$4.92 \%$. These obtained rates were lower than the reported 5.05-5.10\% value for Simmental cattle in Russia for the same lactation period [26].

The determined mean nonfat solids in the milk for all the current research groups was found to be between $9.08-9.31 \%$, higher than the $5.08 \%$ level, found for the Simmental cattle in Russia reported for the same lactation period [26]. Again, the rates obtained in the presented study were higher than the reported mean nonfat solids rates of lactation for Simmental cattle in Turkey (8.6-8.76\%) $[24,25]$.

\section{CONCLUSIONS}

It is crucial to determine whether or not different synchronization methods applied in cows have effects on some milk components, and if there is, to determine at what level and for how long, and the most convenient synchronization method/methods in terms of the effect on the milk composition. Although synchronization in cattle with Ovsynch application may be suggested in terms of changes in the milk fat rate and the other milk compositions in this study, further studies are required to provide this information more comprehensively and in detail. Thus, it was concluded that the results of studies with higher numbers of cows, with the milk samples being collected daily and from individual cows, and the analyses of milk composition to be performed in fresh milk would be useful.

\section{MANUFACTURERS}

${ }^{1}$ Ceva Türkiye. Istanbul, Turkey,

${ }^{2}$ Milkotronic Ltda. Porto, Portugal.

Funding. This study was supported by the TUBITAK 2150578 .

Ethical approval. Ethical approval was obtained from the Local Ethical Committee of Firat University Laboratory Animals (22.07.2015 - 2015/71).

Declaration of interest. The authors report no conflicts of interest. The authors alone are responsible for the content and writing of paper.

\section{REFERENCES}

1 Anonim. 1999. SPSS for Windows. Release 9.0. Standard version. Copyright SPSS Inc.

2 Aslan S. \& Gumen A. 2012. Fertility control programs. In: Kaymaz M., Findik M., Risvanli A. \& Koker A. (Eds.). Obstetric and gynecology in farm animal. Malatya: Medipres, pp.469-517.

3 Auirlist M.J., Walsh B.J. \& Thomson N.A. 1998. Seasonal and factional influences on bovine milk compotition in New Zealand. Journal of Dairy Research. 65(3): 401- 411.

4 Barłowska J., Litwińczuk A., Król J. \& Kedzierska-Matysek M. 2004. Quality of milk production in farms, keeping Simmental cows. Zeszyty Naukowe. Przeglad Hodowlany, 72(1): 161-166.

5 Bedo S., Nikodemusz E., Peresich K. \& Bardos L. 1995. Variation in milk yield and milk composition of dairy cows during lactation. Acta Veterinaria Hungarica. 43(1): 163- 171.

6 Bicoku Y. \& Uruci M. 2013. Preliminary data on milk production and milk components of simmental breed in Albania. Macedonian Journal of Animal Science. 3(1): 17-20.

7 Cavalcante J.L., Telles F.J., Peixoto M.M. \& Rodrigues R.C. 2005. Use of the titratable acidity in the quality control of the milked human milk. Ciência e Tecnologia de Alimentos. 25(1): 103-108.

8 Chang Y., Chen C. \& Lin M. 2012. The macronutrients in human milk change after storage in various Containers. Pediatrics \& Neonatology. 53(3): 205-209.

9 Christodoulopoulos G., Solomakos N., Katsoulos D.P., Minas A., Spyridon K. \& Kritas S.K. 2008. Influence of oestrus on the heat stability and other characteristics of milk from dairy goats. Journal of Dairy Research. 75(1): 64-68. 
10 Craplet C., Thibier M. \& Duplan J.M. 1973. La vache Laitière. Paris: Edition Vigot Frères, 2340p.

11 Eichler S.J. \& Me Fadden T.B. 1996. Effect of stage of lactation and season on udder development and milk yield in pasturejed cows. New Zealand Society for Animal Production. 56(1): 58-60.

12 Fava L.W., Külkamp-Guerreiro I.C. \& Pinto A.T. 2014. Evaluation of physico-chemical characteristics of fresh, refrigerated and frozen Lacaune ewes' milk. Brazilian Journal of Veterinary and Animal Science. 66(6): 1924-1930.

13 Guinot-Thomas P., Ammoury M.A., Roux Y.L. \& Laurent F. 1995. Study of proteolysis during storage of raw milk at $4^{\circ} \mathrm{C}$ : effect of plasmin and microbial proteinases. International Dairy Journal. 5(7): 685-697.

14 Jílek F., Pytloun P., Kubešová M., Štípková M., Bouška J., Volek J., Frelich J. \& Rajmon R. 2008. Relationships among body condition score, milk yield and reproduction in Czech Fleckvieh cows. Czech Journal of Animal Science. 53(9): 357-367.

14 Knight C.H. \& Wilde C.J. 1988. Milk production in concurrently pregnant and lactating goats mated out of season. Journal of Dairy Research. 55(4): 487-493.

16 Konyali A., Ayag B.S. \& Yurdabak S. 2010. Effect of estrus synchronization on dairy goat milk composition. African Journal of Agricultural Research. 5(8): 681-684.

17 Mellado M., Avila N.Y. \& García E. 1998. Estrous synchronization with norgestomet and estradiol valerate at the end of lactation accelerates drying off in goats. Small Ruminant Research. 31(1): 61-66.

18 Moroni P., Pisoni G., Savoini G., Van Lier E., Acuna S., Damian J.P. \& Meikle A. 2007. Influence of oestrus of dairy goats on somatic cell count, milk traits, and sex steroid receptors in the mammary gland. Journal of Dairy Science. 90(2): 790-797.

19 Nistor E., Bampidis V.A. \& Pentea M. 2014. Production traits of Romanian Simmental cows at first lactation. Slovakian Journal of Animal Science. 47(1): 132-141.

20 Pantelić V., Skalicki Z., Petrović M.M. \& Kučević D. 2005. Reproductive characteristics of Simmental breed bull dams. Biotechnology in Animal Husbandry. 21(1): 13-20.

21 Polanski S., Czaka H. \& Latocha M. 1992. The effect of some factors on milk fat and protein percentages of Simmental cows at the Brzozow pedigree farm. Roczniki Naukowe Zootechniki. 19(1): 55-65.

22 Risvanli A., Seker I., Saat N., Karagulle B., Koseman A. \& Kaygusuzoglu E. 2017. The management practices and microbiological quality of a dairy farm with low bulk tank milk somatic cell count. Pakistan Veterinary Journal. 37(2): 175-179.

23 Saat N., Risvanli A., Seker I., Kaygusuzoglu E. \& Koseman A. 2017. Optimization of the estrus synchronization method and determining its effect on bulk tank milk somatic cell count in dairy cattle farming. International Journal of Agriculture and Biology. 19(4): 801-804.

24 Sekerden O. 1999. Effects of calving season and lactation order on milk yield and milk components in Simmental cows. Turkish Journal of Veterinary and Animal Sciences. 23(1): 79-86.

25 Sekerden O., Doğrul F. \& Erdem H. 1999. Blood and milk protein polymorphism and their effects on various production traits in Simmental cows. Turkish Journal of Veterinary and Animal Sciences. 23(1): 87-93.

26 Seltsov V.I. \& Sermyagin A.A. 2014. Assessment of persistence components of milk from simmental cows-heifers of different origin. Russian Journal of Agricultural and Socio-economic Sciences. 12(1):3-8

27 Semacan A. \& Pancarci S.M. 2012. Management of reproduction In: Kaymaz M., Findik M., Risvanli A. \& Koker A. (Eds.). Obstetric and gynecology in farm animal. Malatya: Medipres, pp.99-124

28 Wardell J.M., Hill C.M. \& D'Souza S.W. 1981. Effect of pasteurization and of freezing and thawing human milk on its triglyceride content. Acta Paediatrica Scandinavica. 70(4): 467-471.

29 Weese W.V. \& Thayne D.F. 1973. Effect of freezing rate and thawing rate on milk properties. Journal of Dairy Science. 56(2): 168-170.

30 Haenlein G.F.W. \& Wendorff W.L. 2006. Sheep milk. In: Handbook of Milk of Non-bovine Mammals. Ames: Blackwell Publishing., pp.137-194.

31 Zhang R.H., Mustafa A.F., Ng-Kwai-Hang K.F. \& Zhao X. 2006. Effects of freezing on composition and fatty acid profiles of sheep milk and cheese. Small Ruminant Research 64(3): 203-210.

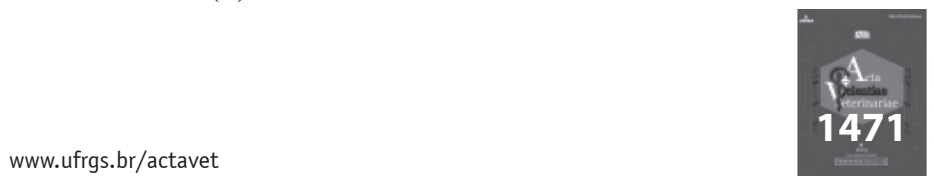

